\title{
PENGARUH KINERJA PEOPLE DAN PHYSICAL EVIDENCE TERHADAP KEPUTUSAN MENGINAP \\ (Survei Terhadap Tamu Hotel Kampung Sumber Alam Garut)
}

\author{
Mia Erisha \\ Universitas Pendidikan Indonesia \\ erishamia@yahoo.com \\ Girang Razati \\ Universitas Pendidikan Indonesia \\ grazupi@gmail.com
}

\begin{abstract}
ABSTRAK
Salah satu hotel yang ikut berperan dalam industri perhotelan di Kabupaten Garut adalah Hotel Kampung Sumber Alam. Hal tersebut membuat Hotel Kampung Sumber Alam Garut menciptakan strategi untuk meningkatkan keputusan menginap melalui kinerja people dan physical evidence yang dapat memberikan kesan dan pengalaman tersendiri bagi para tamunya. Penelitian ini bertujuan untuk 1) memperoleh temuan mengenai kinerja people pada Hotel Kampung Sumber Alam Garut, 2) memperoleh temuan mengenai physical evidence pada Hotel Kampung Sumber Alam Garut, 3) memperoleh temuan keputusan menginap di Hotel Kampung Sumber Alam Garut, 4) memperoleh temuan mengenai seberapa besar pengaruh kinerja people dan physical evidence terhadap keputusan menginap tamu Hotel Kampung Sumber Alam Garut baik secara simultan maupun parsial. Objek penelitian ini adalah tamu Hotel Kampung Sumber Alam Garut. Variabel eksogen dalam penelitian ini adalah kinerja people dan physical evidence dan variabel endogen yaitu keputusan menginap dengan jenis penelitian yang digunakan adalah deskriptif, verifikatif, dan metode yang digunakan adalah explanatory survey dengan teknik simple random sampling dengan jumlah sampel 100 responden. Teknik analisa data yang digunakan adalah path analysis dengan alat bantu software komputer SPSS 21.0 for windows. Hasil yang diperoleh dalam penelitian menyatakan bahwa kinerja people dan physical evidence berpengaruh terhadap keputusan menginap sebesar empat puluh sembilan persen. Dari hasil penelitian terhadap pengujian hipotesis dapat diketahui bahwa kinerja people dan physical evidence memiliki pengaruh yang positif terhadap keputusan menginap.
\end{abstract}

\section{Kata kunci: people, physical evidence, keputusan menginap}

\section{LATAR BELAKANG}

Perkembangan industri perhotelan di Indonesia saat ini boleh dikatakan terus mengalami peningkatan dari tahun ke tahun, namun peningkatan ini harus diimbangi dengan mutu pelayanan yang baik. Sehingga wisatawan yang datang khususnya pengguna jasa hotel tetap merasa nyaman dan puas dengan pelayanan oleh pihak hotel. Pemerintah pun terus berupaya menata dan mengelola potensi objek wisata yang ada untuk meningkatkan jumlah kunjungan wisatawan setiap tahun.

Industri jasa perhotelan memiliki karakteristik tersendiri, yang berbeda dengan sektor industri lainnya. Industri jasa ini menghasilkan dan memasarkan produknya bersamaan dengan dimana produk itu dihasilkan. Konsumen secara langsung dapat memberikan penilaian mengenai kinerja dan pelayanan yang ditawarkan oleh hotel tersebut.

Pariwisata memiliki dampak secara langsung maupun tidak langsung bagi perekonomian nasional maupun lokal. Kegiatan dalam sektor pariwisata mempuyai efek ganda (multiplier effects) yang besar karena terkait dengan berbagai sektor dan kegiatan ekonomi lain. Kegiatan yang terkait dengan pariwisata antara lain adalah perhotelan, restoran, sektor trasportasi (baik darat, laut maupun udara), dan yang tak kalah penting adalah produktifitas yang diuntungkan dengan kunjungan wisatawan, baik domestik maupun mancanegara.

Salah satu destinasi pariwisata yang berkembang di Jawa Barat adalah Kabupaten Garut. Dengan semakin mudahnya akses menuju wilayah Garut, telah menjadikan kabupaten ini sebagai salah satu daerah tujuan wisata di Jawa Barat yang tidak luput dari kunjungan wisnus maupun wisman. Walaupun masih sangat didominasi oleh wisnus, namun situasi sektor pariwisata di Kabupaten Garut tampak semakin meningkat.

Hotel merupakan salah satu jenis akomodasi untuk menunjang dilakukannya kegiatan wisata, oleh karena itu para wisatawan tidak perlu merasa 
khawatir memikirkan tempat mereka bermalam. Kabupaten Garut adalah salah satu kota yang memiliki berbagai macam jenis hotel, baik hotel melati maupun hotel bintang. Berikut Tabel 1 yang menunjukkan jumlah tingkat hunian kamar di Kabupaten Garut.

\section{TABEL 1}

PERSENTASE TINGKAT

PENGHUNIAN KAMAR (TPK)

KABUPATEN GARUT TAHUN 2009-2013

\begin{tabular}{|l|c|c|c|c|c|}
\hline \multicolumn{1}{|c|}{ Uraian } & $\mathbf{2 0 0 9}$ & $\mathbf{2 0 1 0}$ & $\mathbf{2 0 1 1}$ & $\mathbf{2 0 1 2}$ & $\mathbf{2 0 1 3}$ \\
\hline Hotel Berbintang & 40,31 & 43,73 & 27,71 & 48,92 & 47,11 \\
\hline Akomodasi Lainnya $^{*}$ ) & 45,07 & 47,03 & 37,93 & 41,68 & 42,86 \\
\hline
\end{tabular}

Keterangan ${ }^{8}$ : melati, villa dan penginapan

Sumber: Badan Pusat Statistik Garut 2014

Berdasarkan Tabel 1 pada periode tahun 2009-2013 tingkat penghunian kamar (TPK) di Kabupaten Garut mengalami fluktuatif baik pada hotel berbintang dari 40,31 persen tahun 2008 menjadi 47,11 persen tahun 2013, sedangkan TPK akomodasi lainnya mengalami penurunan dari 45,07 persen tahun 2009 menjadi 42,86 persen pada tahun 2013 .

Keputusan menginap pada sebuah hotel merupakan salah satu hal terpenting yang dapat meningkatkan tingkat hunian dan juga dapat meningkatkan pendapatan sebuah hotel. Banyak faktor yang dapat mempengaruhi konsumen memutuskan untuk menginap di sebuah hotel antara lain pelayanan yang diberikan serta fasilitas berupa bukti fisik yang tersedia.

Salah satu hotel yang ikut berperan dalam industri perhotelan di Kabupaten Garut adalah Hotel Kampung Sumber Alam. Hotel ini mengusung konsep yang berbeda dengan kebanyakan hotel di daerah tersebut, konsep kampung yang ditonjolkan diharapkan menjadi daya tarik tersendiri bagi para pengunjung. Hal tersebut juga dimaksudkan untuk meningkatkan tingkat hunian pada Hotel Kampung Sumber Alam Garut. Berikut Tabel 2 yang menunjukkan tingkat hunian Hotel Kampung Sumber Alam Garut:

TABEL 2

\section{TINGKAT PENGHUNIAN KAMAR (TPK) HOTEL KAMPUNG SUMBER ALAM GARUT TAHUN 2010 - 2014}

\begin{tabular}{|c|c|c|c|c|c|}
\hline Hotel & 2010 & 2011 & 2012 & 2013 & 2014 \\
\hline Hotel Kampung Sumber Alam & 19.194 & 19.495 & 18.591 & 18.438 & 18.297 \\
\hline
\end{tabular}

Sumber : Hasil Prasurvei pada Hotel Kampung Sumber Alam Garut 2015

Dari Tabel 2 dapat dilihat tingkat hunian kamar Hotel Kampung Sumber Alam Garut selama lima tahun terakhir mengalami fluktuatif akan tetapi pada tiga tahun terakhir mengalami penurunan penjualan kamar secara signifikan dari tahun 2011 sebesar 19.459 kamar sampai dengan tahun 2014 menjadi 18.297 kamar.

Penurunan tingkat hunian kamar disebabkan adanya pesaing lama maupun baru dibidang perhotelan yang memiliki fasilitas yang lebih baik di daerah tersebut sehingga mengakibatkan menurunnya tingkat hunian karena konsumen yang beralih. Selain itu menurut pihak manajemen menurunnya tingkat hunian disebabkan oleh tamu yang seringkali kurang merasa nyaman dengan kinerja pelayanan yang terkesan lambat dan kurang efisien.

People (sumber daya manusia/orang) sangat penting peranannya dalam hotel karena inti sebuah hotel adalah jasa. Inti sebuah jasa adalah service, dan yang melaksanakan service adalah people. Selain itu physical evidence yang terjaga dengan baik juga dapat mempengaruhi konsumen yang menggunakan jasa tersebut dan mampu untuk menarik minat konsumen baru agar melakukan pembelian.

Ini sejalan dengan pendapat Ratih Hurriyati (2008:71) yang menyatakan pengaruh bauran pemasaran jasa terhadap keputusan pemilihan produk atau jasa adalah sebagai berikut.

Rangsangan pemasaran untuk pembelian produk terdiri dari $4 \mathrm{P}$ untuk produk fisik dan $7 \mathrm{P}$ untuk produk jasa, yaitu harga, tempat, promosi, orang, proses, dan bukti fisik. Rangsangan lain adalah kekuatan-kekuatan utama dalam lingkungan, yaitu: ekonomi, teknologi, politik, dan budaya. Rangsanganrangsangan mempengaruhi pembeli dan berubah menjadi tanggapan pembeli untuk memutuskan pilihan produk atau jasa, merek, waktu dan jumlah.

Selain itu Agung Permana Budi (2013:105) juga mengemukakan "People" merupakan unsur penting dalam penyediaan layanan, perekrutan dan pelatihan staff yang tepat diperlukan untuk menciptakan keunggulan kompetitif. Pelanggan membuat penilaian tentang penyediaan layanan dan pengiriman didasarkan pada orang yang mewakili suatu perusahaan atau organisasi.

Zeithaml, Bitner dan Gremler (2013:26) mengemukakan "Physical evidence The environment in which the service is delivered and where the firm and customer interact, as well as any tangible components that facilitate performace or communication of the service". Bukti fisik merupakan lingkungan fisik dimana jasa disampaikan dan dimana perusahaan dan konsumennya berinteraksi, serta setiap komponen tangible memfasilitasi penampilan atau komunikasi jasa tersebut.

Berdasarkan pada uraian tersebut, penulis merasa perlu untuk melakukan penelitian lebih 
lanjut mengenai people dan physical evidence pada Hotel Kampung Sumber Alam dan pengaruhnya terhadap keputusan menginap pengunjung. Adapun penelitian ini berjudul "Pengaruh Kinerja People dan Physical Evidence terhadap Keputusan Menginap (Survei terhadap Tamu Hotel Kampung Sumber Alam Garut)".

Adapun tujuan penelitian ini adalah untuk memperoleh temuan mengenai : 1) Gambaran kinerja people pada Hotel Kampung Sumber Alam Garut, 2) Gambaran physical evidence pada Hotel Kampung Sumber Alam Garut, 3) Gambaran keputusan menginap di Hotel Kampung Sumber Alam Garut, 4) Besarnya pengaruh kinerja people dan physical evidence terhadap keputusan menginap tamu Hotel Kampung Sumber Alam Garut.

\section{KAJIAN PUSTAKA}

Menurut Don Sexton (2010:14) “Marketing is managing the value perceived by they customers. A marketing strategy is the blueprint for how you will allocate your business objectives." Pemasaran merupakan aktivitas untuk mengantarkan nilai kepada konsumen dan strategi pemasaran merupakan rancangan pengalokasian sumber daya-sumber daya dalam rangka mencapai tujuan bisnis.

Definisi marketing menurut Kotler dan Keller (2012:33) "Marketing is the activity set of institution, and processes for creating, communicating, delivering, and exchanging offerings that have value customers, client, partners, and society at large." Artinya pemasaran adalah kegiatan mengatur lembaga, dan proses untuk membuat, komunikasi, memberikan dan bertukar penawaran yang memiliki nilai bagi konsumen, klien, mitra, dan masyarakat pada umumnya.

Menurut Kotler (2010:152) "Jasa adalah tindakan ataupun perbuatan yang ditawarkan oleh suatu pihak kepada pihak lainnya, dimana sifat dasar dari jasa adalah intangibles (tidak berwujud fisik) dan tidak menghasilkan kepemilikan sesuatu." Dalam ilmu marketing di industri jasa, jasa yang ditawarkan kepada konsumen disebut sebagai produk jadi jasa adalah produk sesuai dengan pendapat Bernard $\mathrm{H}$. Booms and Mary J. Bitner (2011:4) "service as product," jasa adalah produk.

Menurut Rambat Lupiyoadi (2013:92), bauran pemasaran jasa terdiri dari tujuh hal, yaitu sebagai berikut:

1. Produk (product): jenis jasa yang ingin ditawarkan.

2. Harga (price): bagaimana strategi penentuan harga.
3. Lokasi/tempat (place): bagaimana sistem penyampaian yang akan diterapkan.

4. Promosi (promotion): bagaimana promosi yang harus dilakukan.

5. Orang/SDM (people): tipe kualitas dan kuantitas SDM yang akan terlibat dalam pemberi jasa.

6. Proses (process): bagaimana proses dalam operasi jasa tersebut.

7. Layanan pelanggan (customer service): level layanan/jasa yang akan diberikan kepada konsumen.

Selain ketujuh faktor tersebut, ada satu faktor lagi yang tidak kalah pentingnya, yaitu faktor bukti atau lingkungan fisik (physical evidencelenvironment). Bukti fisik berkaitan dengan bagaimana mengelola lingkungan jasa.

Menurut Ayed \& Majed (2012:3) "People, this factor refers to the service employees who produce and deliver the service. It has long been a fact that many services involve personal interactions between customers and the sites employees, and they strongly influence the customer's perception of service quality". Manusia, faktor ini mengacu pada layanan karyawan yang memproduksi dan memberikan layanan. Manusia telah lama menjadi fakta bahwa banyak layanan melibatkan interaksi pribadi antara pelanggan dan sisi karyawan, dan mereka sangat mempengaruhi persepsi pelanggan terhadap kualitas pelayanan.

Sedangkan menurut Zeithaml, Bitner and Gremler (2013:26) "People is all human actors who play a part in service delivery and thus influence the buyer's perceptions; namaely, the firm's personnel, the customer, and other customer in service environment." Orang adalah semua aktor manusia yang berperan dalam penyediaan layanan dan dengan demikian mempengaruhi persepsi pembeli: yaitu personel perusahaan, pelanggan, dan pelanggan lainnya di lingkungan pelayanan.

Menurut Ratih Hurriyati (2010:65) menyatakan bahwa elemen atau unsur dari people adalah:

\section{Service people (Karyawan)}

Penyajian jasa biasanya memegang jabatan ganda, yaitu mengadakan dan menjual jasa tersebut dengan pelayanan yang baik, ramah, cermat, teliti, dan akurat akan menciptakan kepuasan dan kesetiaan pelanggan terhadap perusahaan yang akhirnya meningkatkan nama baik perusahaan.

2. Customer (Pelanggan)

Pelanggan dapat memberikan persepsi kepada pelanggan lain, tentang kualitas jasa yang pernah didapatkannya dari perusahaan. Keberhasilan dari perusahaan jasa berkaitan 
erat dengan seleksi, pelatihan, motivasi dan manajemen dari sumber daya manusia.

Perusahaan atau lembaga yang bergerak dalam bidang usaha jasa, aspek people ini tidak hanya memainkan peranan penting dalam bidang produksi dan operasional saja, tetapi memiliki peranan penting juga dalam melakukan hubungan kontak langsung dengan pelanggan yang juga memungkinkan mempengaruhi pelanggan dalam melakukan keputusan pembelian.

Physical Evidence memberikan kesempatan istimewa kepada perusahaan dalam mengirimkan pesan-pesan yang kuat dan konsisten berkenaan dengan apa yang ingin dicapai, diberikan perusahaan kepada segmen pasar yang dituju, serta pesan-pesan berkenaan dengan karakteristik jasa yang dimiliki. Selain itu bukti fisik juga sangat penting dalam membentuk image atau persepsi karena melalui bukti fisik ini konsumen siap untuk mengidentifikasikan dan membandingkan suatu perusahaan jasa dengan perusahaan jasa lainya.

Menurut Zeithaml, Bitner and Gremler (2013:26) "The environment in which the service is delivered and where firm and costumer interact and any tangible component that facilitate performance or communication of the service." Lingkungan fisik di mana jasa disampaikan dan dimana perusahaan dan konsumennya berinteraksi, serta setiap komponen tangible memfasilitasi penampilan atau komunikasi jasa tersebut. Sedangkan Agung Permana Budi (2013:107) mengungkapkan bukti fisik (physical evidence) merupakan lingkungan fisik tempat jasa diciptakan dan langsung berinteraksi dengan konsumen.

Unsur-unsur dalam physical evidence (bukti fisik) merupakan salah satu upaya mengurangi tingkat resiko yang kerap dialami perusahaan dengan menawarkan atau memperbaiki setiap komponen dari unsur physical evidence dan memberikan keamanan serta kenyamanan bagi konsumen. Physical evidence (bukti fisik) menunjukan kesempatan istimewa bagi perusahaan untuk mengirim pesan yang konsisten dan kuat yang berkenaan dengan upaya perusahaan tersebut mencapai segmen pasar yang dituju.

Keputusan menginap dalam penelitian ini mengadopsi pengertian keputusan pembelian karena keduanya mempunyai kesamaan yang artinya, tamu yang datang ke hotel pasti akan melakukan pembelian jasa.

Perilaku konsumen dalam membeli barang atau jasa tercermin dalam proses pengambilan keputusan pembelian. Menurut Sproles dalam Safiek Mokhlis dan Hayatul Safrah Salleh (2009:575) mengungkapkan "A consumer decision-making style is a patterned, mental, cognitive orientation towards shopping and purchasing, which constantly dominates the consumer's choises. These traits are ever-present, predictable, central driving forces in decisionmaking."

Gaya pengambilan keputusan konsumen memiliki motif, mental, kognitif orientasi terhadap belanja dan pembelian yang terusmenerus mendominasi pilihan konsumen. Karakter ini selalu hadir, dapat diprediksi, kekuatan pendorong utama dalam pengambilan keputusan.

Kotler dan Keller (2012:170) terdapat lima dimensi keputusan yang dilakukan oleh pembeli, yaitu:

\section{Brand choice}

Kosumen harus memutuskan merek mana yang akan dibeli. Setiap merek memiliki ciri-ciri tersendiri. Dalam hal ini perusahaan harus mengetahui bagaimana konsumen dalam memilih merek.

2. Dealer

Konsumen harus memutuskan penyalur mana yang akan dikunjungi. Dalam menentukan penyalur, konsumen mempunyai pandangan yang berbeda-beda, bisa dikarenakan faktor lokasi yang dekat, harga yang murah, persediaan barang yang lengkap, kenyamanan berbelanja dan lain sebagainya.

\section{Quantity}

Konsumen dapat mengambil keputusan mengenai seberapa banyak produk yang akan dibelinya pada suatu saat. Pembelian dilakukan mungkin lebih dari satu. Dalam hal ini perusahaan harus mempersiapkan banyaknya produk sesuai dengan keinginan yang berbeda-beda dari setiap pembeli.

4. Timing

Keputusan konsumen dalam memilih waktu pembelian bisa berbeda-beda, misalnya ada yang membeli setiap hari, setiap satu minggu sekali, dua minggu sekali atau satu bulan sekali bergantung pada kebutuhan produk yang akan dibelinya.

\section{Payment method}

Konsumen dapat mengambil keputusan tentang metode pembayaran atau cara pembayaran produk yang dibeli, apakah secara tunai atau cicilan. Keputusan tersebut akan mempengaruhi keputusan tentang penjual dan jumlah pembeliannya. Dalam hal ini perusahaan harus mengetahui keinginan pembeli terhadap cara pembayarannya.

Berdasarkan uraian tersebut dapat diketahui bahwa kinerja people dan physical evidence terhadap keputusan menginap tamu maka disusun paradigma yang sesuai seperti berikut : 


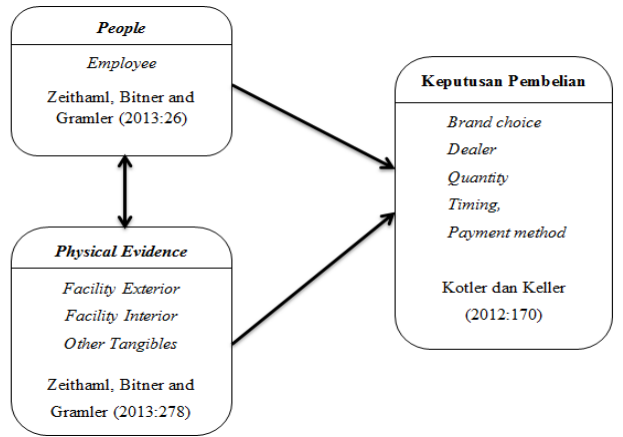

GAMBAR 1

\section{METODELOGI PENELITIAN}

Penelitian ini dilakukan untuk mengetahui pengaruh kinerja people dan physical evidence terhadap keputusan menginap Hotel Kampung Sumber Alam. Adapun yang menjadi objek penelitian sebagai variabel bebas atau independent yaitu kinerja people $\left(\mathrm{X}_{1}\right)$ yang meliputi employee serta physical evidence $\left(\mathrm{X}_{2}\right)$ yang meliputi facility exterior, facility interior, other tangibles. Terhadap Keputusan Menginap sebagai variabel terikat atau dependent $(\mathrm{Y})$ brand choice, dealer, quantity, timing, dan payment method pada Hotel Kampung Sumber Alam.

Jenis penelitian ini adalah penelitian deskriptif dan verifikatif. Penelitian deskriptif bertujuan untuk memperoleh deskripsi atau gambaran mengenai kinerja people dan physical evidence juga memperoleh gambaran mengenai keputusan menginap tamu Hotel Kampung Sumber Alam. Sedangkan penelitian verifikatif bertujuan untuk menguji kinerja people dan physical evidence terhadap keputusan menginap tamu Hotel Kampung Sumber Alam. Berdasarkan jenis penelitian di atas maka dilakukan pengumpulan data di lapangan. Metode yang digunakan dalam penelitian ini adalah explanatory survey. Populasi dalam penelitian ini yakni tamu Hotel Kampung Sumber Alam Garut yaitu sebanyak 1.537 orang. Sampel yang dapat mewakili dari populasi berjumlah 94 orang. Untuk keperluan penelitian ukuran sampel ditambah 6 orang sehingga ukurannya menjadi 100 orang.

Secara statistik, hipotesis yang akan diuji dalam rangka pengambilan keputusan penerimaan atau penolakan hipotesis dapat dirumuskan sebagai berikut:

Hipotesis secara simultan:

Ho: $\rho \leq 0$, artinya tidak terdapat pengaruh kinerja people dan physical evidence terhadap keputusan menginap tamu Hotel Kampung Sumber Alam Garut

Ha: $\rho>0$, artinya terdapat pengaruh kinerja people dan physical evidence terhadap keputusan menginap tamu Hotel Kampung Sumber Alam Garut

Hipotesis secara parsial:

Ho: $\rho \leq 0$, artinya tidak terdapat pengaruh kinerja people terhadap keputusan menginap tamu Hotel Kampung Sumber Alam Garut

Ha: $\rho>0$, artinya terdapat pengaruh kinerja people terhadap keputusan menginap tamu Hotel Kampung Sumber Alam Garut

Ho: $\rho \leq 0$, artinya tidak terdapat pengaruh physical evidence terhadap keputusan menginap tamu Hotel Kampung Sumber Alam Garut

Ha: $\rho>0$, artinya terdapat pengaruh physical evidence terhadap keputusan menginap tamu Hotel Kampung Sumber Alam Garut

\section{HASIL PENELITIAN DAN PEMBAHASAN}

\section{Pembahasan Deskriptif}

A. Tanggapan Tamu

a. Kinerja People

Berdasarkan hasil penelitian yang bersifat empirik, diketahui bahwa tamu memiliki respon yang cukup tinggi terhadap kinerja people. Dalam rangka memenuhi kebutuhan dan keinginan pelanggan pada dimensi employee dapat diterima dengan baik oleh tamu, sehingga dapat meningkatkan kenyamanan saat menginap di Hotel Kampung Sumber Alam Garut.

\section{b. Physical Evidence}

Berdasarkan hasil penelitian yang bersifat empirik, diketahui bahwa tamu memiliki respon yang cukup tinggi terhadap physical evidence. dimana banyak responden yang suka terhadap konsep desain fasilitas eksterior yang diusung oleh pihak Hotel Kampung Sumber Alam Garut sehingga dimensi ini memiliki persentase tertinggi.

\section{c. Keputusan Menginap}

Berdasarkan hasil penelitian yang bersifat empirik, diketahui bahwa tamu memiliki respon yang cukup tinggi terhadap keputusan menginap. Didapatkan persentase tertinggi pada dimensi brand choice dimana banyak responden yang lebih memilih brand Hotel Kampung Sumber Alam Garut bahkan hingga merekomendasikan kepada orang lain.

\section{Pembahasan Verifikatif}

Gambar 2 di bawah ini menjelaskan secara lengkap mengenai pengaruh masing-masing variabel Kinerja People $\left(\mathrm{X}_{1}\right)$ dan Physical Evidence $\left(\mathrm{X}_{2}\right)$ terhadap Keputusan Menginap $(\mathrm{Y})$ di Hotel Kampung Sumber Alam Garut secara berurut. 


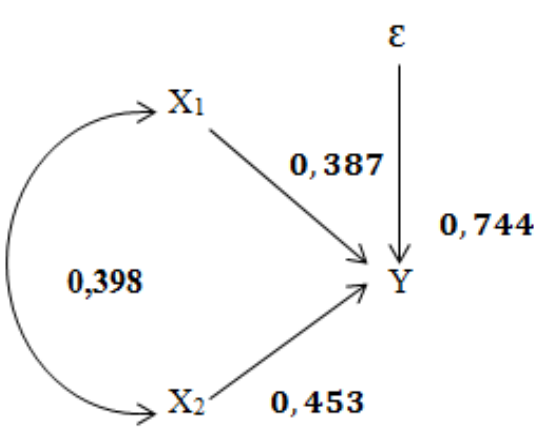

GAMBAR 2

DIAGRAM JALUR PENGUJIAN

HIPOTESIS PENGARUH KINERJA

PEOPLE DAN PHYSICAL EVIDENCE

TERHADAP KEPUTUSAN MENGINAP

DI HOTEL KAMPUNG SUMBER ALAM

GARUT

Keterangan:

$\mathrm{X}_{1} \quad$ : Variabel Kinerja People

$\mathrm{X}_{2} \quad$ : Variabel Physical Evidence

Y : Variabel Keputusan Menginap

$\varepsilon \quad$ : Epsilon (variable lain yang mempengaruhi)

Berdasarkan diagram jalur pengujian hipotesis pada Gambar 2 maka dilakukan perhitungan untuk mengetahui pengaruh langsung dan tidak langsung antara dimensi-dimensi yang dipaparkan. Berdasarkan Tabel 3 dapat dilihat bahwa pengaruh langsung maupun tidak langsung antara kinerja people dan physical evidence terhadap keputusan menginap. yang paling besar pengaruhnya secara parsial yaitu physical evidence $\left(\mathrm{X}_{2}\right)$ terhadap keputusan menginap $(\mathrm{Y})$ sebesar $(0,161: 0,257)$ x $100 \%=62,7 \%$. Sedangkan pengaruh kinerja people $\left(\mathrm{X}_{1}\right)$ terhadap keputusan menginap $(\mathrm{Y})$ sebesar $(0,096: 0,257) \mathrm{X}$ $100 \%=37,4 \%$

TABEL 3

\section{PENGARUH LANGSUNG DAN TIDAK} LANGSUNG $X$ TERHADAP $Y$

\begin{tabular}{|c|c|c|c|c|c|}
\hline \multirow{2}{*}{ Responden } & \multirow{2}{*}{ Variabel } & \multirow{2}{*}{$\begin{array}{c}\text { Pengaruh } \\
\text { Langsung } \\
\text { Terhadap Y }\end{array}$} & \multicolumn{2}{|c|}{$\begin{array}{c}\text { Pengaruh Tidak } \\
\text { Langsung Melalui : }\end{array}$} & \multirow[t]{2}{*}{ TOTAL } \\
\hline & & & $\mathbf{X}_{1}$ & $\mathbf{X}_{2}$ & \\
\hline \multirow{2}{*}{$\begin{array}{l}\text { Tamu Hotel } \\
\text { Kampung } \\
\text { Sumber } \\
\text { Alam Garut }\end{array}$} & People & 0,061 & - & 0,035 & 0,096 \\
\hline & $\begin{array}{l}\text { Physical } \\
\text { Evidence }\end{array}$ & 0,126 & 0,126 & - & 0,161 \\
\hline \multicolumn{5}{|c|}{$\mathrm{R}^{2} \mathrm{YX} \ldots, \mathrm{YXX}$} & 0,257 \\
\hline
\end{tabular}

Sumber: Hasil pengolahan data 2014

Dari tabel di atas juga dapat diketahui bahwa total koefisien jalur dari kinerja people dan physical evidence terhadap keputusan menginap adalah sebesar 0,257 sehingga dapat diketahui nilai dari koefisien residu melalui rumus:

$$
\begin{aligned}
& \rho Y \varepsilon=\sqrt{1-R^{2 Y_{(X 1.1, \ldots X 1.4)}}} \\
& \rho Y \varepsilon=\sqrt{1-0,257} \\
& \rho Y \varepsilon=0,712
\end{aligned}
$$

Hasil tersebut menunjukkan bahwa kinerja people $\left(\mathrm{X}_{1}\right)$ dan physical evidence $\left(\mathrm{X}_{2}\right)$ secara simultan mempengaruhi terhadap keputusan menginap (Y) pada responden tamu Hotel Kampung Sumber Alam Garut yaitu sebesar $49 \%$. Sedangkan pengaruh dari luar untuk tamu Hotel Kampung Sumber Alam Garut sebesar $(0,712)^{2} \mathrm{x}$ $100 \%=51 \%$, dipengaruhi variabel lain yang tidak masuk ke dalam penelitian ini.

\section{UJI HIPOTESIS}

\section{A. Pengujian Simultan}

Adapun hasil pengujian hipotesis dengan menggunakan uji statistik path analysis (analisis jalur) secara keseluruhan (simultan) dapat dilihat pada Tabel 4 berikut ini.

Tabel 4 menunjukan pengujian untuk uji $\mathrm{F}$ yang diambil dari Anova dengan tingkat probabilitas $(\mathrm{Sig})=0,000$ karena nilai $\mathrm{Sig} \leq 0,1$, maka keputusannya adalah Ho ditolak. Artinya secara simultan atau keseluruhan terdapat pengaruh positif antara kinerja people dan physical evidence terhadap keputusan menginap tamu Hotel Kampung Sumber Alam Garut.

TABEL 4

PENGUJIAN SECARA SIMULTAN

\begin{tabular}{|c|c|c|c|c|c|}
\hline Responden & $\begin{array}{c}\text { Hipotesis } \\
\text { Alternatif }\end{array}$ & F Hitung & F Tabel & Keputusan & Kesimpulan \\
\hline $\begin{array}{c}\text { Tamu Hotel } \\
\text { Kampung } \\
\text { Sumber Alam }\end{array}$ & $\begin{array}{c}\mathrm{X}_{1} \text { dan } \mathrm{X}_{2} \\
\text { secara } \\
\text { simultan } \\
\text { berpengaruh } \\
\text { terhadap Y }\end{array}$ & 16,732 & 3,25 & $\mathrm{H}_{0}$ ditolak & Signifikan \\
\hline \\
\multicolumn{3}{|c|}{ Sumber: Hasil Pengolahan Data 2014 (Menggunakan SPSS 21.0 for Windows) } \\
\hline
\end{tabular}

\section{B. Pengujian Parsial}

Pengujian parsial dapat dilakukan setelah dipastikan adanya pengaruh yang signifikan antara kinerja people dan physical evidence terhadap keputusan menginap di Hotel Kampung Sumber Alam Garut pada uji simultan. Tabel 5 menunjukkan hasil perhitungan dari pengujian parsial yang dapat dilihat sebagai berikut.

TABEL 5 PENGUJIAN PARSIAL

\begin{tabular}{|c|c|c|c|c|c|}
\hline Responden & $\begin{array}{c}\text { Hipotesis } \\
\text { Alternatif }\end{array}$ & F Hitung & F Tabel & Keputusan & Kesimpulan \\
\hline $\begin{array}{c}\text { Tamu Hotel } \\
\text { Kampung } \\
\text { Sumber Alam }\end{array}$ & $\begin{array}{c}\mathrm{X}_{1} \text { dan } \mathrm{X}_{2} \\
\text { secara } \\
\text { simultan } \\
\text { berpengaruh } \\
\text { terhadap Y }\end{array}$ & 16,732 & 3,25 & $\mathrm{H}_{0}$ ditolak & Signifikan \\
\hline
\end{tabular}

Sumber: Hasil Pengolahan Data 2014 (Menggunakan SPSS 21.0 for Windows) 
Berdasarkan Tabel 5 dapat diketahui bahwa $\mathrm{X}_{1}$ dan $\mathrm{X}_{2}$ berpengaruh secara signifikan terhadap variabel $\mathrm{Y}$ dimana $t_{\text {Hitung }}>\mathrm{t}_{\text {Tabel }}$ dengan tingkat signifikan $\leq 0,1$, artinya terdapat pengaruh antara people $\left(\mathrm{X}_{1}\right)$ dan physical evidence $\left(\mathrm{X}_{2}\right)$ terhadap keputusan menginap (Y).

\section{KESIMPULAN DAN REKOMENDASI}

\section{KESIMPULAN}

1. Gambaran mengenai kinerja people yang dilaksanakan oleh Hotel Kampung Sumber Alam Garut termasuk pada kategori cukup tinggi. Hal tersebut menunjukkan bahwa kinerja people dalam hal ini yang meliputi emlpoyee (karyawan) ditanggapi dengan cukup baik oleh tamu hotel. Sikap karyawan hotel merupakan indikator yang memiliki skor tertinggi.

2. Gambaran mengenai physical evidence yang diusung oleh Hotel Kampung Sumber Alam Garut termasuk pada kategori cukup tinggi. Dimensi facility exterior merupakan dimensi yang dianggap paling berperan penting bagi responden.

3. Gambaran dari keputusan menginap di Hotel Kampung Sumber Alam Garut yang diukur dari dimensi brand choice, dealer, quantity, timing dan payment method berada pada kategori sedang. Hal ini menunjukkan bahwa keputusan tamu untuk menginap di Hotel Kampung Sumber Alam Garut masih cukup baik. Dimensi dealer merupakan dimensi yang paling dominan dimana responden memilih hotel tersebut dengan beberapa pertimbangan yang dilakukan.

4. Kinerja People dan Physical Evidence yang dilakukan oleh Hotel Kampung Sumber Alam Garut secara keseluruhan memiliki pengaruh yang cukup signifikan terhadap keputusan menginap tamu dengan perolehan nilai koefisien determinasi sebesar $49 \%$. Sedangkan pengaruh dari luar yang berasal dari variabel lain yang tidak diteliti dalam penelitian ini sebesar 51\%. Hal ini menunjukan bahwa semakin optimalnya kinerja people dan physical evidence maka semakin tinggi pula pengaruhnya terhadap keputusan menginap tamu Hotel Kampung Sumber Alam Garut.

\section{REKOMENDASI}

1. Kinerja People

a. Meningkatkan kinerja karyawan dapat dilakukan dengan berbagai cara seperti dengan mengedepankan pelayanan yang berkesan bagi para tamu sehingga tamu merasa nyaman.

2. Physical Evidence a. Facility exterior yang merupakan desain bagian luar tentu sangat berpengaruh pada keputusan pembelian jasa, begitu pula dengan desain bangunan Hotel Kampung Sumber Alam Garut. Konsep yang diusung oleh pihak hotel secara keseluruhan telah berjalan cukup baik akan tetapi masih terdapat kekurangan yang dirasa oleh tamu sehingga pihak hotel hendaknya membenahi beberapa bagian hotel tesebut.

b. Facility interior di Hotel Kampung Sumber Alam sebaiknya ditingkakan, karena dengan meningkatkan fungsi dari facility interior tersebut maka desain kamar Hotel Kampung Sumber Alam Garut akan semakin menarik dimata tamu sehingga tamu akan merasa nyaman untuk berlama-lama berada di dalam kamar. Selain itu perlunya menambah berbagai kelengkapan fasilitas pendukung di beberapa ruangan.

c. Other tangibles di Hotel Kampung Sumber Alam Garut sebaiknya lebih menyesuaikan pakaian yang digunakan untuk setiap divisi karyawan yang berada di hotel, juga dibuat semenarik mungkin sehingga terlihat perbedaan yang mencolok dengan hotel lainnya. Selain itu juga perlunya memaksimalkan fungsi brosur dan website sebagai sumber informasi yang penting bagi tamu dengan membuat desain semenarik mungkin sehingga tamu merasa ingin untuk membacanya tanpa merasa jenuh yang hanya berisi tulisan-tulisan.

3. Keputusan Menginap

a. Beberapa responden lebih memilih namanama hotel yang lebih terkenal atau populer untuk menginap dengan demikian pihak Hotel Kampung Sumber Alam Garut perlu melakukan promosi secara besar-besaran sehingga mampu meningkatkan popularitasnya dikalangan tamu dan lebih dikenal oleh masyarakat luas. Selain itu penambahan produk dan jasa yang ditawarkan sebagai bahan pertimbangan tamu dalam memilih juga perlu dilakukan agar lebih bervariasi.

b. Fasilitas yang tersedia di Hotel Kampung Sumber Alam Garut bagi para responden dirasa masih kurang sehingga perlu diadakan peninjauan kembali untuk fungsifungsi dari fasilitas tersebut. Menambah berbagai fasilitas lainnya yang dibutuhkan juga sebagai sarana penunjang bagi para tamu merupakan hal yang dapat dilakukan oleh pihak hotel demi kenyamanan para tamu.

c. Jumlah menginap rata-rata yang dilakukan oleh responden berkisar kurang dari tiga hari. Untuk meningkatkannya dapat 
dilakukan dengan berbagai cara salah satunya pihak manajemen Hotel Kampung Sumber Alam Garut membuat paket-paket menginap yang bervariasi tentunya dengan harga yang relatif terjangkau, dengan begitu diharapkan mampu meningkatkan jumlah menginap yang dilakukan oleh para tamu.

d. Beberapa responden tidak terlalu peduli dengan waktu-waktu tertentu yang digunakan saat menginap. Hal tersebut dapat ditingkatkan dengan membuat acara atau event-event tertentu seperti menjalin kerjasama antar perusahaan untuk mengadakan acara di Hotel Kampung Sumber Alam Garut dengan harga yang relatif murah.

e. Metode pembayaran yang digunakan oleh Hotel Kampung Sumber Alam Garut sudah cukup bervariasi akan tetapi tetap mempunyai kekurangan menurut sebagian responden. Hal tersebut dapat diperbaiki dengan menambah varain metode pembayaran seperti menerima pembayaran dengan uang asing, ataupun mnyediakan money changer untuk penukaran uang asing dan juga memudahkan tamu dalam melakukan pembayaran.

4. Pengaruh kinerja people dan physical evidence adalah signifikan terhadap keputusan menginap, oleh karena itu penulis merekomendasikan :

a. Selalu memfasilitasi para karyawan untuk terus melakukan pengembangan diri dengan memberikan berbagai pelatihan, motivasi juga bonus sehingga memicu semangat para karyawan untuk bekerja lebih baik lagi sehingga mampu mempengaruhi tamu menginap di Hotel Kampung Sumber Alam Garut.

b. Melakukan berbagai perbaikan secara terjadwal dan menambah beberapa fasilitas yang dapat membuat nyaman para tamu yang datang dan menginap di Hotel Kampung Sumber Alam Garut dan meberikan kesan tersendiri kepada para tamu sehingga mampu untuk melakukan pembelian ulang dikemudian hari.

c. Membuat strategi mengenai kinerja people dan physical evidence sesuai dengan kebutuhan yang dapat diterima dan dirasakan langsung oleh tamu sehingga memberikan kenyamanan lebih dibanding dengan hotel pesaing lainnya.

d. Membuat strategi-strategi lain untuk menarik tamu dari hotel pesaing sehingga menjadi tamu tetap di Hotel Kampung Sumber Alam Garut.

\section{DAFTAR PUSTAKA}

Alma, Buchari dan Ratih Hurriyati. 2008. Manajemen Corporate dan Strategi Pemasaran Jasa Pendidikan. Fokus pada Mutu Layanan dan Prima. Bandung: Alfabeta

Ayed Al Muala \& Majed Al Qurneh. 2012. Assessing the Relationship between Marketing Mix and Loyality through Tourists Satisfaction in Jordan Curative Tourism. Malaysia: American academic \& Scholarly Research Journal Vol. 4 No. 2 Pp. 3

Badan Pusat Statistik Garut Dalam Angka 20092013

Budi, Agung Permana. 2013. Manajemen Marketing Perhotelan. Yogyakarta: CV Andi Offset

Hasil Prasurvei pada Hotel Kampung Sumber Alam Garut 2015

Kotler, Philip dan Kevin L. Keller. 2012. Marketing Management. New Jersey: Pearson Prentice Hall.

Kotler, Philip. 2010. Prinsip-Prinsip Pemasaran, Alih Bahasa Benyamin Molan. Jakarta: Erlangga

Lupiyoadi, Rambat. 2013. Manajemen Pemasaran Jasa, Edisi 3. Jakarta: Salemba Empat

Safiek Mokhlis dan Hayatul Safrah Salleh. 2009. Consumer Decision-Making style in Malaysia: An Exploratory Study of Gender Differences. European Journal of Social Sciences - Volume 10, No. 4.

Sexton, Don. 2010. "How To Use The Most Powerful Ideas In Marketing To Get More Customers And Keep Them". Journal of Air Transport Management, 10, pp. 435-439

Zeithaml, Valerie A, Mary Jo Bitner. Dwayne D. Gremler. 2013. Service Marketing: Integrating Customer Focus Across the Firm $6^{\text {th }} e d$. Boston: Mc Graw Hill 